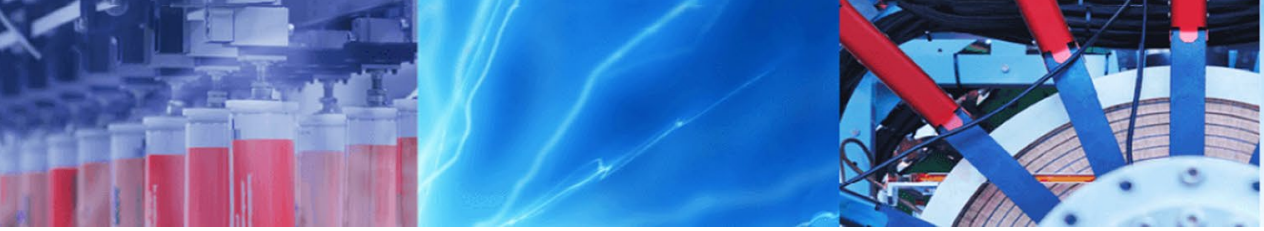

Research Article

\title{
Modeling runoff and sediment yield of Kesem dam watershed, Awash basin, Ethiopia
}

\author{
Tesfu Abebe ${ }^{1} \cdot$ Bogale Gebremariam ${ }^{2}$
}

(C) The Author(s) 2019 OPEN

\begin{abstract}
Runoff and sediment yield modeling is important in the watershed to alleviate soil erosion and reservoir sedimentation. This paper presents runoff and sediment yield modeling of Kesem dam watershed, which has a drainage area of $2660 \mathrm{~km}^{2}$. Soil and Water Assessment Tool (SWAT, version 2009) integrated with ArcGIS software (version 9.3) was used to simulate the stream flow and sediment concentration of Kesem dam watershed situated in Awash River basin for the period from 1994 to 2010 . The model was calibrated manually by adjusting sensitive parameters using observed data from 2001 to 2006, and validation was done using observed data from 2007 to 2010. The model performance was checked by statistical model performance evaluators such as the coefficient of determination $\left(R^{2}\right)$, Nash-Sutcliffe model efficiency and Percent bias and it shows that the model has a high potential in the estimation of runoff and sediment yield. The test of the model SWAT by simulating the streamflow and sediment concentration was satisfactory. From the generated spatial distribution of runoff and Sediment yield of the Kesem dam watershed, subbasins 12 and 13 were high runoff and sediment yielding sub-basins among the 41 sub-basins. The outputs of this study will be used by water resource managers and decision makers to conserve soil and water in the sub-watershed levels.
\end{abstract}

Keywords Runoff · Sediment yield · SWAT model $\cdot$ Kesem dam watershed

\section{Introduction}

Runoff and sediment yield modeling is important in the watershed [1-3]. Even though watershed has only one outlet point, it is characterized by different socio-economic activities, spatial, hydrological and climatic variability. Spatial and temporal variability have the visible change in the quantity of runoff decreased or increases with the size of watershed and shape [4-7]. Modeling the hydrological process such as runoff and sediment yield of the watershed is useful to manage the natural resources. In turn, this can be helped for sustainable soil and water management, which are key resources of the community living in the watershed.
During rainfall, part of the precipitation is intercepted [8] or infiltrates into the ground, and the remainder flows over the land surface as runoff run to the nearest stream or river. Runoff has different characteristics [9] and affected by natural and man-made activities. For instance, in paved areas, storm-water runoff is much larger than non-paved areas. As runoff flows over the land surface, it picks up and transports potential pollutants and necessary soil materials [10]. Sometimes runoff occurs based on the degree of soil infiltration capacity and action of water force the soil erosion event will appear. Erosion rates are frequently measured in small fractional-hectare plots and the erosion agent $[11,12]$ and affected by different factors, for example, rainfall intensity $[13,14]$; these factors have a dynamic role in the erosional behavior of soil $[15,16]$.

Tesfu Abebe, rmta@gmail.com; Bogale Gebremariam, bgmariam@gmail.com | Department of Water Resources and Irrigation Engineering, College of Engineering and Technology, Jigjiga University, Jijiga, Ethiopia. ${ }^{2}$ Faculty of Hydraulic and Water Resources Engineering, Water Technology Institute, Arba Minch University, Arba Minch, Ethiopia. 
Soil erosion accelerated by human activity and has a serious ecological impact that costs a nation due to on-site effects such as soil nutrient and economic loss and offsite effects due to reservoir sedimentation [17]. Additionally, in the downstream irrigation and water resources project damages [18]. Furthermore, erosion also reduces the products of crops which resulting from soil fertility reduction [19-22], flood hazards, and this, further, has further problems of water availability, water quality, food security, and food supply $[23,24]$. At farming land, erosion problem initiated by tillage practice in which the soil surface destructed [25], overgrazing [26-28], deforestation and poor land management practice; especially on slope land. Erosion and sedimentation are a sequential phenomenon first occurred in the upstream of the watershed. Then, due to one of soil erosion agent that is water, after passing the erosion process, it is deposited at plain or mouth of the stream channels as sedimentation. They affect sustainable water resource planning and management and reservoir life [29].

Runoff and sediment yield can be estimated using different watershed models [3,30-36]. Out of several runoff and sediment yield simulating models Soil and Water Assessment Tool (SWAT) has been used to predict runoff and sediment yield [37, 38], SWAT efficiency was good with streamflow prediction [39, 40]. A lot of studies have been reported using SWAT to predict surface runoff, soil erosion, sediment yield and assessment of best management practices [41-44]. Researchers reported that in Ethiopia the model was calibrated and validated with good performance on the hydrological process and management practices [45-54].Therefore, in this paper, SWAT was used to accomplish the general objectives of this study which is modeling of runoff and sediment yield by SWAT model of Kesem dam watershed and the specific objectives (1) to test the reliability of the model SWAT by simulating the streamflow and sediment concentration in Kesem dam watershed and (2) to predict and generate the spatial distribution of runoff and sediment yield in each sub-basin of Kesem dam watershed.

\section{Materials and methods}

\subsection{Study watershed description}

The study was performed in the Kesem dam watershed, which is the part of the Awash River basin. Kesem River is passing through Kesem dam watershed; before draining into the Awash River it has been contributing water for Kesem irrigation project available lower of Kesem dam. The Kesem dam watershed, located between latitudes around $8^{\circ} 50^{\prime}$ and $9^{\circ} 20^{\prime} \mathrm{N}$ and longitudes $39^{\circ} 00^{\prime}$ and $40^{\circ} 00^{\prime} \mathrm{E}$.
It has a watershed drainage area of about $2660 \mathrm{~km}^{2}$ up to the outlet point of the Kesem dam (Fig. 1).

The climate of the study area varies from arid in the lower altitudes to semi-arid in the high altitudes of the watershed. The rainfall distribution of the Kesem dam watershed is low around the outlet of the watershed as compared with the middle and the highest altitude of the watershed (high rainfall) [55]. On the other hand, the Kesem watershed has to mean maximum temperature of $38^{\circ} \mathrm{C}$ and mean minimum temperature of $15^{\circ} \mathrm{C}$. However, the weather condition upstream of the watershed is cool and moist with elevation variation between 1500 and $3488 \mathrm{~m}$ above mean sea level [55].

The Kesem Dam and its reservoir are located on the Kesem river channel; it is located at the southern end of the Afar depression (rift) in Afar regional state of Ethiopia. It lies between the UTM 37 zone coordinates of $580,000-608,000 \mathrm{mE}$ and 9,810,000-1,020,000 mN.

\subsection{Model input data and database creation}

For proper implementation of this study, Geographic Information system (GIS) software, physically based watershed model SWAT and other data processing software's has been used. Since the model is physically based [3], the surface properties such as digital elevation model (DEM), stream network, digital soil map, digital land use and land cover map, climatic and hydrological input data of study watershed were used.

\subsubsection{Database creation and spatial data analysis}

The DEM of study area (Fig. 2a) was downloaded from ASTER GDEM website (http://gdem.ersdac.jspacesystems. or.jp/) a resolution of $30 \mathrm{~m}$ by $30 \mathrm{~m}$. Using the geographic positioning system (GPS) reading of the main outlet point (Latitude $9.15^{\circ} \mathrm{N}$, Longitude $39.78^{\circ} \mathrm{E}$ ) of the Kesem dam watershed; watershed boundary, stream network and drainage pattern of the watershed were developed (Fig. 3). In addition, from DEM, the relevant flow parameters flow accumulation, flow direction and slope were derived. The other spatial model input data were land use and land cover, soil map of the study area. The land use and land cover are one of the most important factors that affect runoff, evapotranspiration and surface erosion in any watershed. The digital 2008 land use and land cover and soil map of the Kesem dam watershed was obtained from the Ministry of Agriculture of Ethiopia.

On the basis of land use and land cover map of Ethiopia, the extracted land use and land cover (LU/LC) map of the study watershed was reclassified using the SWAT model in order to correspond with the parameters in the SWAT database (Fig. 2c). In the same manner, the soil map 


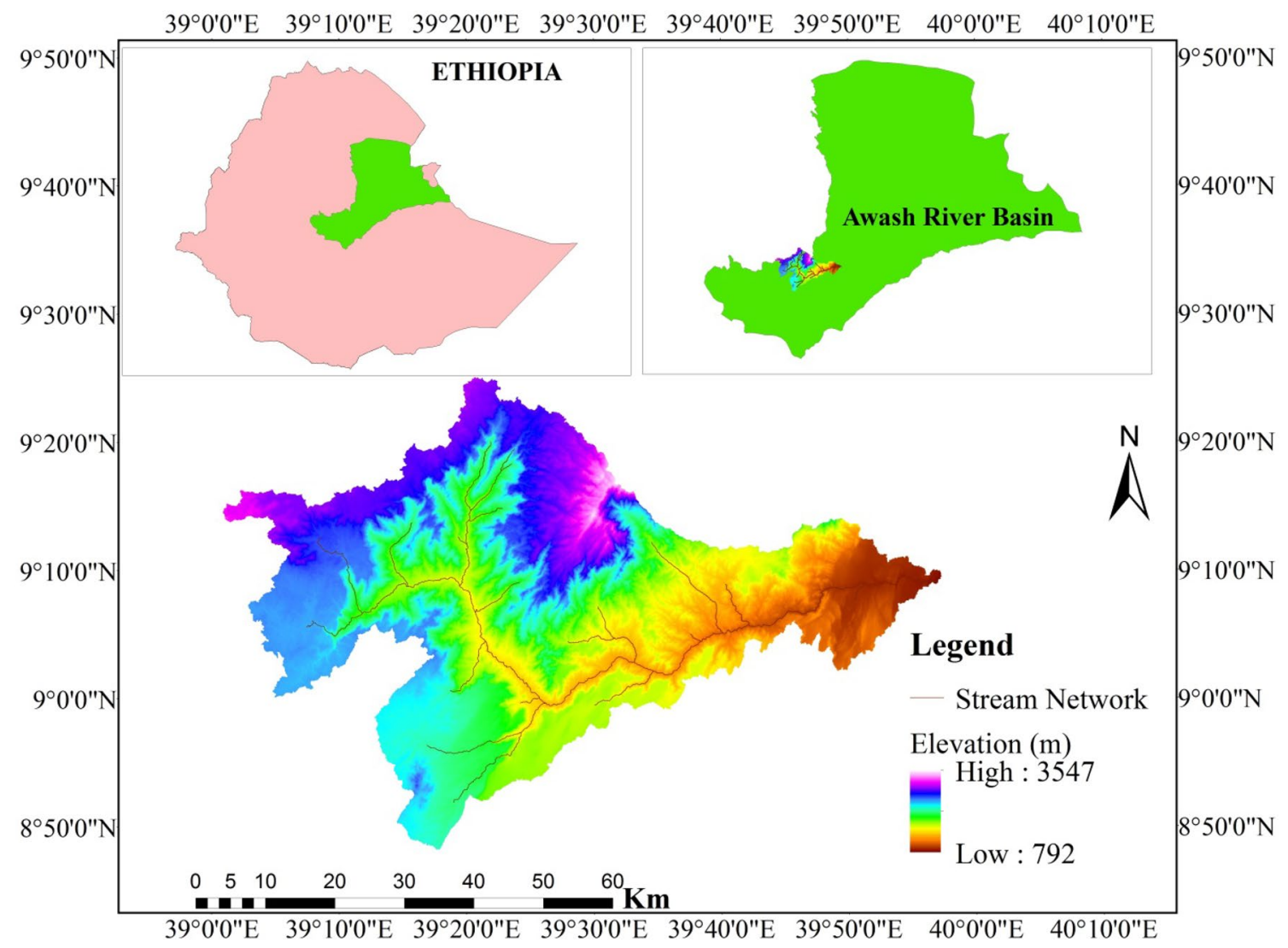

Fig. 1 Location map of the study area

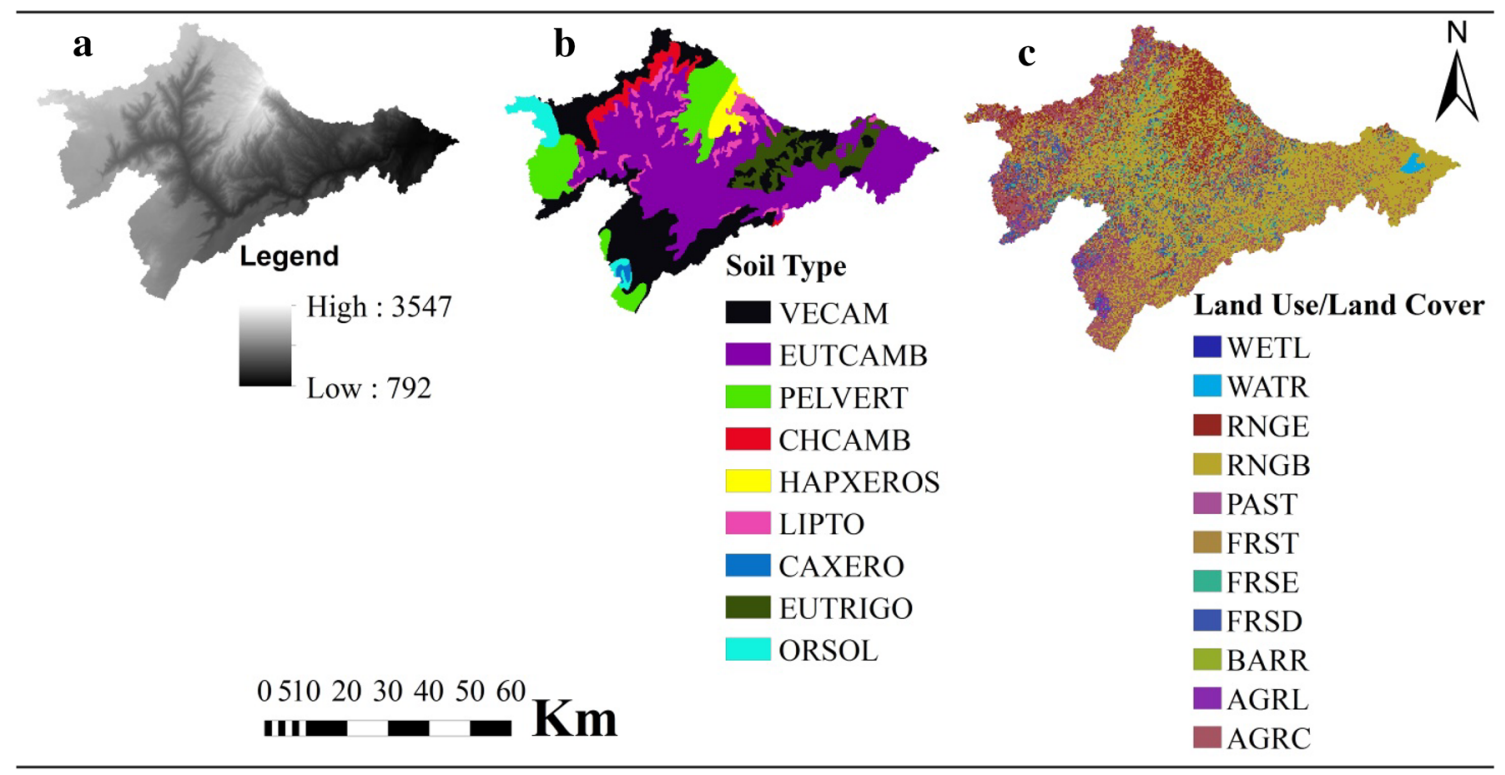

Fig. 2 Spatial data inputs a DEM, b soil and c LU/LC map of Kesem dam watershed

of the study watershed also reclassified in order to correspond with the parameters in the SWAT user soil database
(Fig. 2b). For successful reclassification, a look-up Table (4-letter SWAT code for LU/LC in DBF file format,) and soil 


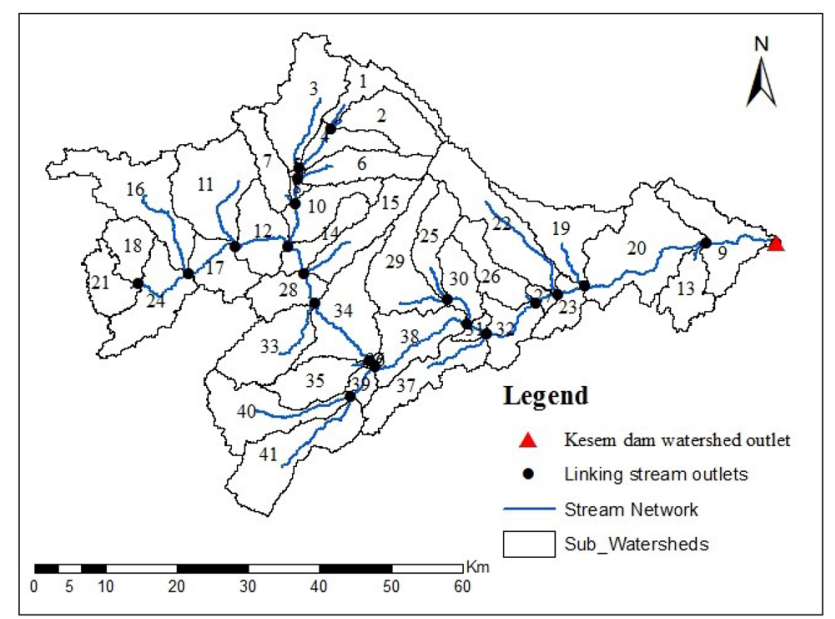

Fig. 3 Sub-watersheds of Kesem dam watershed

look-up table in text file format was prepared. After LU/LC and the soil SWAT code is assigned to all map categories, the estimated values of the area-percent (\%) coverage are provided below in Table 1. These procedures were applied to determine the hydrologic parameters of each land and soil category simulated within each sub-watershed.

The SWAT model requires different soil physical and chemical properties such as soil texture, available water content, hydraulic conductivity, bulk density and organic carbon content for different layers of soil. In this particular study, the soil properties of the Kesem dam watershed were taken from Kesem dam and irrigation project of Kesem watershed design document of soil laboratory tests [55].

\subsection{Hydro-meteorological data}

Hydro-meteorological data is needed by the SWAT model to simulate the hydrological behavior of the watershed.
The meteorological data required for this study were obtained from the national meteorological agency of Ethiopia in the time range from 1994 to 2010 for this study. The meteorological data collected daily value for precipitation, maximum and minimum air temperature, wind speed, relative humidity and the sunshine (converted to solar radiation). With the availability of data distribution of each metrological station in the study area, only six stations selected for this study those data recorded is better as compared with the others (Table 2).

The hydrological data were required to identify the most significant sensitive parameters for the calibration and validation model procedures. The streamflow data were collected from Ministry of Water, Irrigation and Electricity from the hydrology and water quality directorate department in the time series data (1994-2010) for Kesem River which crosses the Kesem Dam watershed at Awara Melka gauging station. Due to discontinuous time series sediment record data measured by Water, Irrigation and Electricity, using stream flow and measured suspended sediment data, sediment load data was generated in the continuous time step, by developing sediment rating curve.

Table 2 Meteorological stations in and around the Kesem dam watershed

\begin{tabular}{lrrr}
\hline \multirow{2}{*}{ Gaging station } & \multicolumn{2}{c}{ Geographical location in UTM } & \multirow{2}{*}{ Elev. $(\mathrm{m})$} \\
\cline { 2 - 3 } & \multicolumn{1}{c}{ Lat. $(\mathrm{m})$} & \multicolumn{1}{c}{ Long. $(\mathrm{m})$} & \\
\hline Debre Berhan & $1,068,601.3$ & $556,681.6$ & 2750 \\
Chefa Donsa & $991,169.6$ & $514,656.6$ & 2392 \\
Sendafa & $980,244.7$ & $604,460.7$ & 2550 \\
Methara & $1,011,681.6$ & $502,349.9$ & 944 \\
Awara Melka & $1,013,431.1$ & $1,013,431.1$ & 960 \\
Bologiorgis & $974,601.5$ & $538,489.3$ & 1963 \\
\hline
\end{tabular}

Table 1 SWAT based redefined LU/LC and soil types of the Kesem dam watershed

\begin{tabular}{|c|c|c|c|c|c|c|c|}
\hline LU/LC type & LU/LC_code & Area $\left(\mathrm{km}^{2}\right)$ & LU/LC (\%) & Soil type & Soil_code & Area $\left(\mathrm{km}^{2}\right)$ & Soil type (\%) \\
\hline Forest-deciduous & FRSD & 169.21 & 6.03 & Calcic Xerosols & CAXERO & 10.7 & 0.38 \\
\hline Agricultural land-generic & AGRL & 49.07 & 1.75 & Chromic Cambisols & CHCAMB & 93.88 & 3.34 \\
\hline Agricultural land-close-grown & AGRC & 720.18 & 25.65 & Eutric Cambisols & EUTCAMB & 1192.71 & 42.47 \\
\hline Bare land & BARR & 11.26 & 0.4 & Eutric Regosols & EUTRIGO & 191.67 & 6.83 \\
\hline Range-grasses & RNGE & 295.43 & 10.5 & Haplic Xerosols & HAPXEROS & 60.45 & 2.15 \\
\hline Forest-evergreen & FRSE & 146.17 & 5.21 & Leptosols & LIPTO & 130.38 & 4.65 \\
\hline Forest-mixed & FRST & 57.84 & 2.06 & Orthic Solonchaks & ORSOL & 81.19 & 2.89 \\
\hline Wetlands-mixed & WETL & 2.72 & 0.1 & Pellic Vertisols & PELVERT & 332.18 & 11.83 \\
\hline Range-brush & RNGB & 1340.76 & 47.74 & Vertic Cambisols & VECAM & 715.02 & 25.46 \\
\hline Pasture & PAST & 4.41 & 0.16 & & & & \\
\hline Water & WATR & 11.13 & 0.4 & & & & \\
\hline
\end{tabular}




\subsection{SWAT model setup, calibration and validation}

Modeling of runoff and sediment yield of the Kesem Dam watershed was built using SWAT model. SWAT [3] is the interface of GIS software and has been using readily available GIS input data. The model was designed using the Kesem Dam watershed extracted and properly projected data, such as DEM, 2008 LU/LC, soil map and weather data.

The first step in the SWAT model setup was watershed delineation, sub-watershed [56] and naturally existing stream network determination using the Kesem Dam watershed DEM (Fig. 2a). Next, the study watershed was divided into sub-watersheds based on the concept of flow direction and accumulation; and sub-watersheds were further subdivided into smallest unit called HRUs which consist of unique combinations of homogeneous soil and land use properties and slope range $[42,57]$. The cyclic motion of water in nature is determined by the hydrologic cycle and it has been simulated in SWAT using the water balance equation defined below $[56,57]$.

$$
\mathrm{SW}_{\mathrm{t}}=\mathrm{SW}_{\mathrm{o}}+\sum_{\mathrm{i}=1}^{\mathrm{t}}\left(\mathrm{R}_{\text {day }}-\mathrm{Q}_{\text {surf }}-\mathrm{E}_{\mathrm{a}}-\mathrm{W}_{\text {seep }}-\mathrm{Q}_{\mathrm{gw}}\right)
$$

where $S W_{t}$ is final soil water content $(\mathrm{mm}), \mathrm{SW}_{\mathrm{o}}$ is initial soil water content $(\mathrm{mm}), R_{\text {day }}$ is the precipitation $(\mathrm{mm}), Q_{\text {surf }}$ is the surface runoff $(\mathrm{mm}), \mathrm{W}_{\text {seep }}$ is the water entering vadose zone $(\mathrm{mm}), \mathrm{E}_{\mathrm{a}}$ is the evapotranspiration $(\mathrm{mm})$ and $\mathrm{Q}_{\mathrm{gw}}$ is the return flow $(\mathrm{mm})$ and $\mathrm{t}$ is time (days).

In the SWAT model, the surface runoff volume is predicted from daily rainfall using the soil conservation service curve number method [58] and the model estimates the peak runoff rate with a modified rational formula for each HRU. Runoff flows through the channel system was estimated using a variable storage coefficient method developed by Williams [59]. In the SWAT model, erosion and sediment yield is estimated for each HRU caused by rainfall and runoff with the Modified Universal Soil Loss Equation (MUSLE) [59]:

$$
\begin{aligned}
\operatorname{Sed}_{\mathrm{i}}= & 11.8\left(\mathrm{Q}_{\text {surf }} \cdot \mathrm{q}_{\text {peak }} \cdot \mathrm{A}_{\text {hru }}\right)^{0.56} * \mathrm{~K}_{\mathrm{USLE}} * \mathrm{C}_{\mathrm{USLE}} \\
& * \mathrm{P}_{\mathrm{USLE}} * \mathrm{LS}_{\mathrm{USLE}} * \mathrm{CFGR}
\end{aligned}
$$

where 11.8 is the unit conversion factor, Sed is the sediment yield in ton per day (ton/day), $Q_{\text {surf }}$ is the surface runoff volume $(\mathrm{mm} / \mathrm{ha}), \mathrm{q}_{\text {Peak }}$ is peak runoff rate in $\mathrm{m}^{3} / \mathrm{s}, \mathrm{A}_{\text {hru }}$ is the area of HRU (ha), $K_{\text {USLE }}$ is the soil erodibility factor, $C_{\text {USLE }}$ is cover and management factor, $P_{\text {USLE }}$ is support practice factor, LS is topographic factor, CFRG is course fragment factor.

Based on the default values of model parameters, the sensitive input parameters for both stream flow and sediment yield was identified and calibrated manually [60] at the dam site gaging station. The model was calibrated by changing the stream flow and sediment yield parameters until the model simulation results were fallen in the acceptable range as per the model performance evaluation measures. The model performance was checked based on visual inspections and statistical model evaluators defined in Sect. 2.5 below. The calibration was done first for streamflow, followed by sediment yield. The calibrated parameters of the model were then validated using an independent data set of streamflow and sediment yield data out of the range period assigned during the calibration in monthly time basis.

\subsection{Model performance evaluation}

In order to evaluate the performance of the model such as its quality and reliability of prediction compared to the observed values the methods for goodness-of-fit measures of model predictions used during the calibration and validation periods. These numerical model performance measures are coefficient of determination $\left(R^{2}\right)$, Nash-Sutcliffe simulation efficiency (NSE) [61] and Percent bias (PBIAS) (Fig. 4).

The coefficient of determination $\left(R^{2}\right)$, it is the square of the Pearson product moment correlation coefficient [63]; which describes the proportion of the total variance in the observed data; i.e. explained by the model. The value of $\mathrm{R}^{2}$ greater than 0.6 (Fig. 4) and close to one is the higher of the agreement between the simulated (flows and sediment load) with the observed (flows and sediment load).

$\mathrm{R}^{2}=\left(\frac{\sum_{i=1}^{n}\left(Q_{i}^{o b}-Q_{\text {mean }}^{o b}\right)\left(Q_{i}^{\text {sim }}-Q_{\text {mean }}^{\text {sim }}\right)}{\left[\sum_{i=1}^{n}\left(Q_{i}^{o b}-Q_{\text {mean }}^{o b}\right)^{2} \sum_{i=1}^{n}\left(Q_{i}^{\text {sim }}-Q_{\text {mean }}^{\text {sim }}\right)^{2}\right]^{0.5}}\right)^{2}$

where $Q_{i}^{o b}$ is observed value (flow in $\mathrm{m}^{3} / \mathrm{s}$ or sediment in tons), $Q_{\text {mean }}^{\text {ob }}$ is the average observed of $n$ value, $Q_{i}^{\text {sim }}$ simulated value (flow in $\mathrm{m}^{3} / \mathrm{s}$ or sediment in tons), $Q_{\text {mean }}^{\text {sim }}$ averaged simulated of $n$ value and $n$ is the number of observations.

Nash-Sutcliffe efficiency (NSE): NSE is a normalized statistic that determines the relative magnitude of the residual variance compared to the measured data variance. NSE indicates that the plot of observed values with simulated values of the data fits the 1:1 line.

$\mathrm{NSE}=1-\frac{\sum_{i=1}^{n}\left(Q_{i}^{o b}-Q_{i}^{\text {sim }}\right)^{2}}{\sum_{i=1}^{n}\left(Q_{i}^{o b}-Q^{\text {mean }}\right)^{2}}$

NSE ranges between $-\infty$ and 1 ( 1 inclusive), NSE $>0.5$ is a good model performance (Fig. 4); NSE equal to 1 is being the optimal value.

Percent bias (PBIAS) as introduced by Moriasi et al. [64] and measures the average tendency of the simulated data to 
Fig. 4 SWAT run and parameter analysis [62]

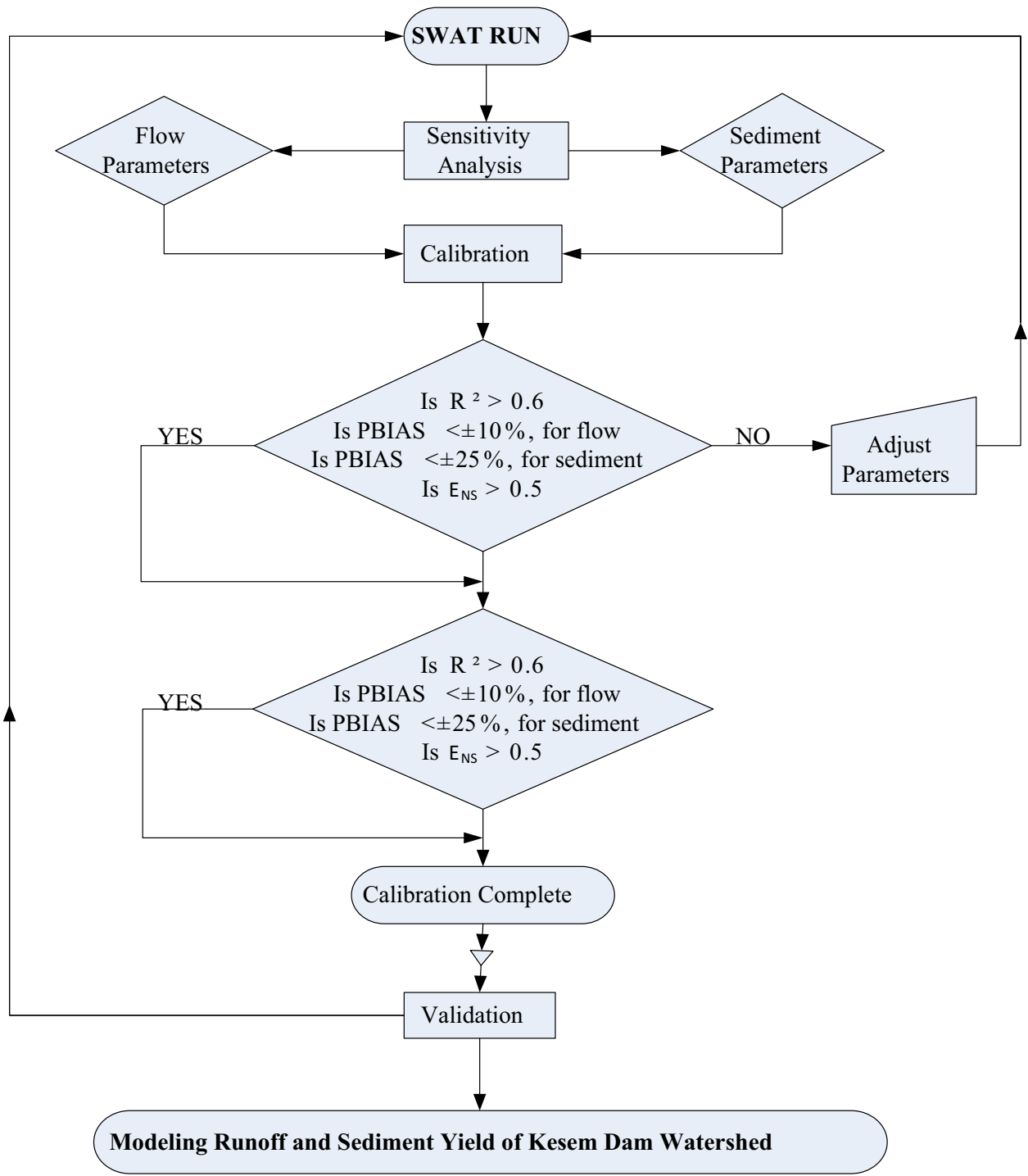

be larger or smaller than their observed data [65]. The PBIAS low-magnitude values show accurate model simulation. A positive value of PBIAS indicates model is an underestimation and negative values indicate model is overestimation bias [65].

PBIAS $=\frac{\sum_{i=1}^{n}\left(Q_{i}^{o b}-Q_{i}^{s i m}\right) *(100)}{\sum_{i=1}^{n}\left(Q_{i}^{o b}\right)}$

\section{Results and discussions}

\subsection{Model calibration and validation}

The first step in the calibration and validation process in the SWAT model is the identification of the most sensitive parameters for a given watershed that have a significant impact on specific model outputs such as streamflow and sediment yields [66]. Sensitivity analysis was done and it was found that the Available water capacity (Sol_Awc) was the most sensitive parameter, followed by the base flow Soil depth (Sol_Z) and Plant evaporation compensation factor (Epco) reported as a medium sensitive parameter in the stream flow parameters (Table 3) and parameters such as USLE_P support practice factor and USLE_C cover factor were the most sensitive parameters in the sediment yields (Table 5) in the Kesem dam watershed. Hence, these most significant parameters were considered for further model calibration and validation (Tables 4 and 5).

\subsubsection{Model calibration}

The model calibration was run for a period of 7 years from Jan/1/2000 to Dec/31/2006. From these periods of simulation, the first year (2000) was set as a warm-up period. 
Table 3 Kesem dam watershed stream flow parameters and degree of sensitivity

\begin{tabular}{lllll}
\hline Rank & Flow parameters & Swat_code & Sensitivity index & $\begin{array}{l}\text { Degree of } \\
\text { sensitivity }\end{array}$ \\
\hline 1 & Available water capacity (mm water/mm soil) & Sol_Awc & $9.15 \mathrm{E}-01$ & High \\
2 & Soil depth $(\mathrm{mm})$ & Sol_Z & $6.39 \mathrm{E}-01$ & High \\
3 & Plant evaporation compensation factor & Epco & $2.44 \mathrm{E}-02$ & Medium \\
4 & Maximum potential leaf area index & Blai & $9.73 \mathrm{E}-03$ & Small \\
5 & Soil conductivity $(\mathrm{mm} / \mathrm{h})$ & Sol_K & $6.35 \mathrm{E}-03$ & Small \\
6 & Average slope steepness $(\mathrm{m} / \mathrm{m})$ & Slope & $4.50 \mathrm{E}-03$ & Small \\
7 & Soil evaporation compensation factor & Esco & $2.63 \mathrm{E}-03$ & Small \\
8 & Soil Albedo & Sol_Alb & $2.61 \mathrm{E}-03$ & Small \\
9 & Threshold depth of water required for return & Gwqmn & $2.42 \mathrm{E}-03$ & Small \\
& flow to occur(mm) & & & Small \\
10 & Initial SCS CN II value $(\%)$ & Cn2 & $2.21 \mathrm{E}-03$ & Small \\
11 & Alpha base flow recession constant (days) & Alpha_Bf & $1.41 \mathrm{E}-03$ & Small \\
\hline
\end{tabular}

Table 4 Kesem dam watershed calibrated flow parameters

\begin{tabular}{llll}
\hline Rank & $\begin{array}{l}\text { Parameter (swat__ } \\
\text { code) }\end{array}$ & $\begin{array}{l}\text { Allowable range in } \\
\text { model }\end{array}$ & Fitted value \\
\hline 1 & Sol_Awc & $\pm 25 \%$ & 0.001 \\
2 & Sol_Z & $\pm 25 \%$ & $12 \%$ \\
3 & Epco & $0.01-1$ & 0.923 \\
4 & Blai & $0-1$ & 0.25 \\
5 & Sol_K & \pm 25 & 0.006 \\
6 & Slope & \pm 25 & 0.0045 \\
7 & Esco & $0.01-1$ & 0.95 \\
8 & Sol_Alb & $0-0.25$ & 0.16 \\
9 & Gwqmn & $0-5000$ & 21 \\
10 & Cn2 & $\pm 25 \%$ & 74.2 \\
11 & Alpha_Bf & $0-1$ & 0.048 \\
12 & Canmx & $0-10$ & 2.5 \\
\hline
\end{tabular}

Table 5 Kesem dam watershed calibrated sediment yield parameters

\begin{tabular}{lcl}
\hline Parameter & Recommended range & Final value \\
\hline USLE_P & $0.0-1.0$ & 0.651 \\
USLE_C & $0.0-1.0$ & 0.0042 \\
Spcon & $0.0001-0.01$ & 0.0015 \\
Spexp & $1.0-2.0$ & 1.325 \\
Ch_Erod & $0-1.0$ & 0.0027 \\
Ch_Cov & $0-1.0$ & 0.00012 \\
\hline
\end{tabular}

Therefore, the calibration performed for 6 years from Jan/1/2001 to Dec/31/2006 for streamflow and sediment yields of the Kesem dam watershed. The calibration process was done manually until the acceptable agreement happens between observed and simulated data [56]. This
Table 6 Summary of calibration and validation period of stream flow and sediment yield parameter model performance indicators

\begin{tabular}{lcllll}
\hline & \multicolumn{2}{l}{ Stream flow } & & \multicolumn{2}{l}{ Sediment yields } \\
\cline { 5 - 6 } \cline { 5 - 6 } & $\begin{array}{l}\text { Calibration } \\
(2001-2006)\end{array}$ & $\begin{array}{l}\text { Validation } \\
(2007-2010)\end{array}$ & & $\begin{array}{l}\text { Calibration } \\
(2001-2006)\end{array}$ & $\begin{array}{l}\text { Validation } \\
(2007- \\
2010)\end{array}$ \\
\hline $\mathrm{R}^{2}$ & 0.87 & 0.86 & 0.85 & 0.77 \\
$\mathrm{E}_{\mathrm{NS}}$ & 0.84 & 0.87 & 0.84 & 0.76 \\
$\mathrm{PBIAS} \mathrm{( \% )}$ & -8.25 & 4.03 & & 7.29 & 14.4 \\
\hline
\end{tabular}

activity determined in the monthly time basis. Moreover, the fit between observed and simulated streamflow and sediment yield data was checked by statistical techniques provided below in Table 6. Streamflow and sediment yield hydrographs were developed to compare observed and simulated streamflow and sediment yield values for the calibration periods in monthly time step (Figs. 5, 6).

Statistical model performance evaluator of calibration result shows a good agreement between the observed and simulated streamflow and sediment yield parameters [67] (Table 6) and the model recommended for the monthly time basis [64]. Moreover, previously SWAT was not applied in the study area; following this fact, the calibrated results indicate that the model recommended for predicting watershed process of the Kesem dam watershed.

As indicated in Table 6, the model slightly overestimated the simulated streamflow result in some months of the years during the calibration period and underestimated the sediment yield simulation results. This was as a result of high rainfall and the occurrence of runoff, which has a high record period. But the time series trend of the gauged flow was well fitted for monthly time steps. 
Fig. 5 Calibrated stream flow hydrograph at Kesem dam gauging station
Fig. 6 Calibration sediment yield hydrograph at Kesem dam gauging station
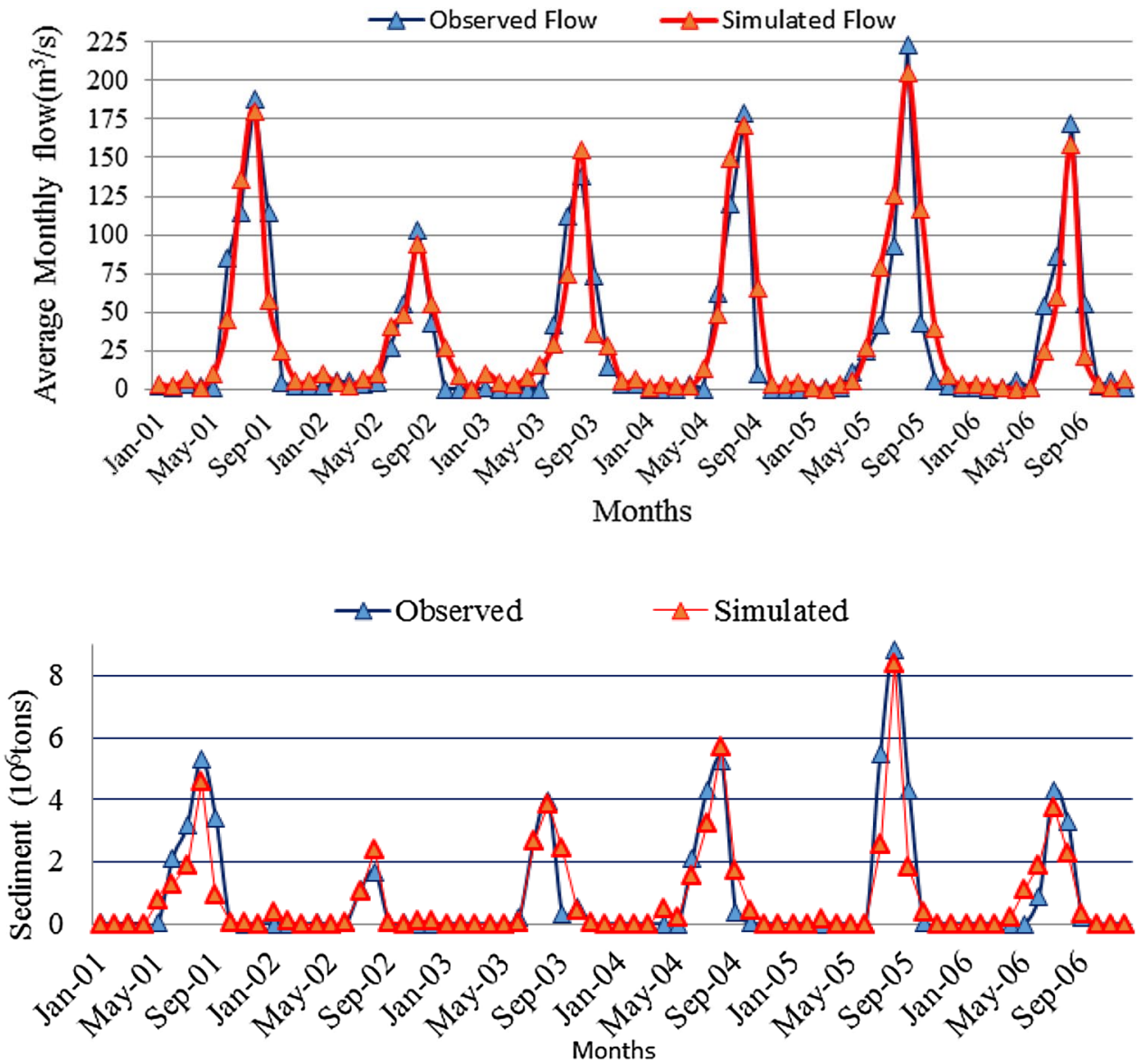

\subsubsection{Model validation}

Model validation was carried out over a 4 year period (Jan/1/2007 to Dec/31/2010) for both streamflow and sediment yield parameters. An agreement between measured values (streamflow and sediment concentration) and simulated outputs (streamflow and sediment concentration) on monthly time steps as shown by $\mathrm{R}^{2}$, ENS, and PBIAS (Table 6), the model parameters represent the processes happen in the Kesem dam watershed.

Figures 7 and 8 clearly show a reasonably good agreement between observed and simulated streamflow and sediment yield hydrographs for monthly time steps during the validation period.

The long-term results of the flow a seasonal variation (Fig. 9) show that there was a good agreement between observed and simulated average values of streamflow; even though the model underestimates streamflow from June to middle August of the study period. This shows that there was a high measured flow value which greater than the simulated results. The peak, the average flow volume, at Kesem Dam sites was $246.98 \mathrm{~mm}^{3}$ and $261.20 \mathrm{~mm}^{3}$ of simulated and observed respectively. In addition, the watershed average annual runoff was estimated to $543.67 \mathrm{~mm}$ (Appendix).

\subsection{Runoff and sediment yield spatial distribution}

Runoff and sediment yield of each sub-basin was not uniform. This was as a result of rainfall distribution and its intensity [68]. In fact, only rainfall amount and its distribution have not impact on runoff and erosion rather the intensity [69]. Actually, good LU/LC cover has positive effects on the reduction of runoff and sediment yield. Several studies prevail, that LU/LC can be controlled erosion by covering the soil surface by the canopy and reduce the mechanical action happen at the soil surface by intercepting the raindrop [70]. In the Kesem Dam watershed, the most sediment yielding sub-basins were $2,4,9,12,13,20$, 23, 27 and 36 (Fig. 10c). These sub-basins were covered most areas by range-brush lands followed by agricultural lands close grown crops (Fig. $2 \mathrm{c}$ and Table 1).

The slope of these high sediment yielding sub-basins were $>15 \%$ slope area coverage. The runoff and sediment yield distribution, for instance, sub-basins 12 and 13 were high (Fig. 10b, c) and characterized by maximum rainfall distribution (Fig. 10a). The least sediment 
Fig. 7 Stream flow hydrograph of validation period at Kesem dam gauging station
Fig. 8 Sediment yield hydrograph of validation period at Kesem dam gauging station
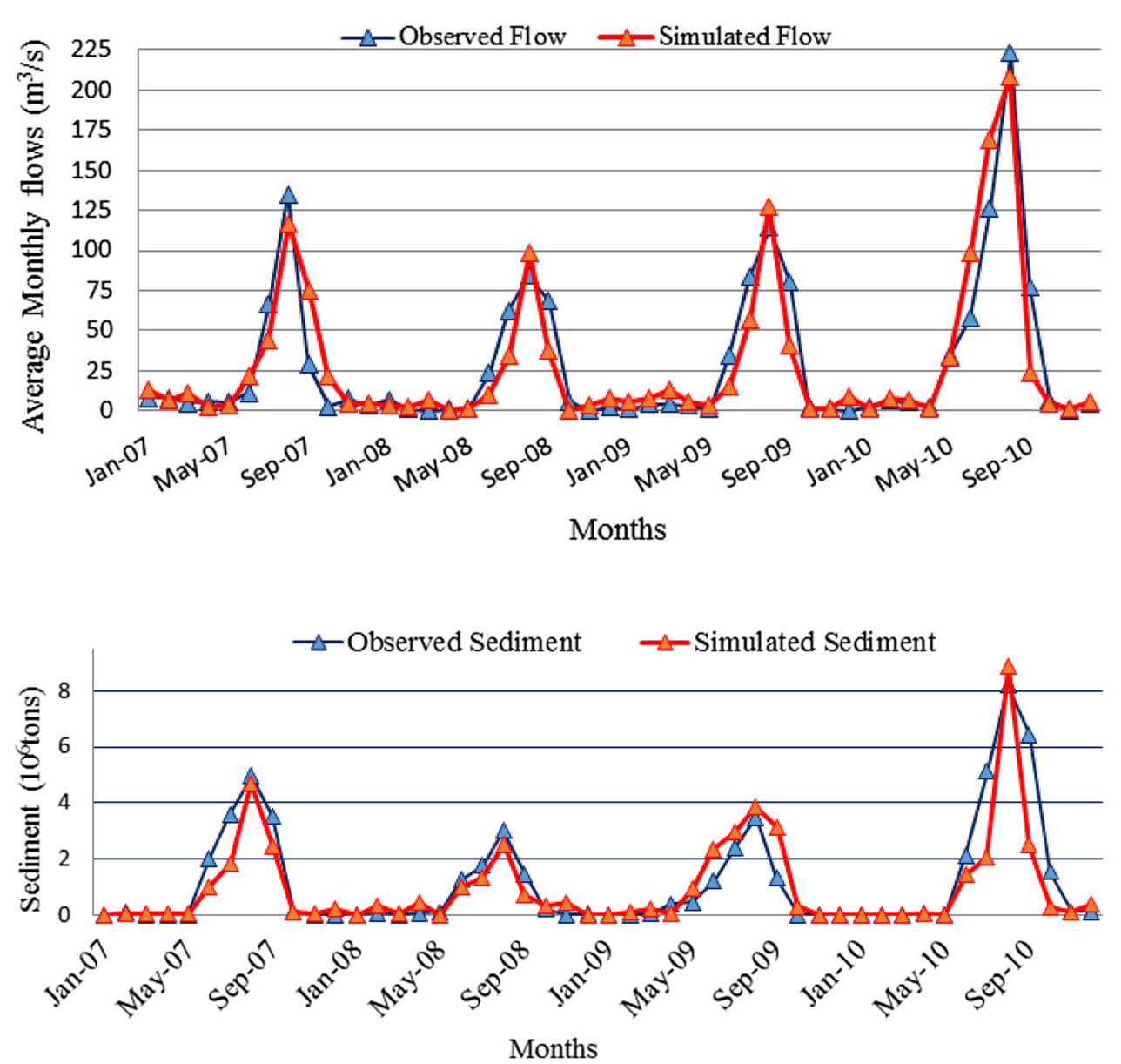

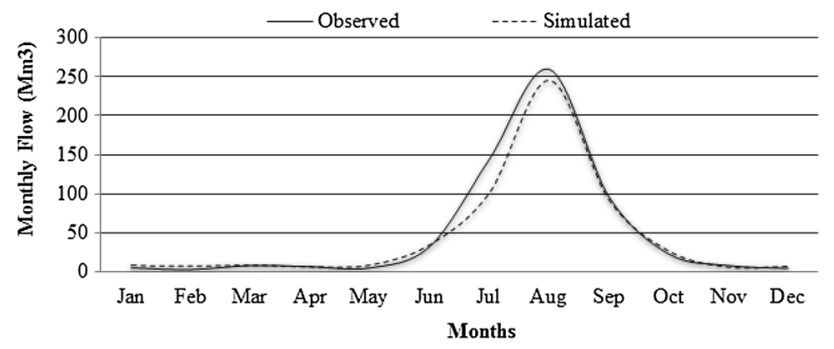

Fig. 9 Long term mean monthly flow hydrograph of Kesem River at Kesem dam (1994-2010)

yielding sub-basins were 1, 16, 18 and 21 (Fig. 10c). The slope of these sub-basins were less than $15 \%$, although they had the slope between 7 and 15\% they deliver least sediment may be due to well-covered land use/cover.

As shown in Fig. 11, precipitation and runoff alone have no impact on sediment yield. For instance, in sub-basins 1, 16, 18 and 21 there was high precipitation and runoff but less sediment yield. This is maybe the response of $L U / L C$, soil resistance to erosion, slope (Fig. 12) and other management practice found in the watershed [71].
Figure 12 shows that the relationship between slope and sediment yield had a direct relation in some subbasins; example 12, 13, 23, 27 and 36 produced high sediment yields. But in the other sub-basins, it is inverse relation, i.e. high slope and low sediment and vice versa, this might be due to the LU/LC, soil resistance, and rainfall intensity. For instance, Fig. 12, sub-basins 2, 10, 22, 26, 30 and 41 shows the inverse relation. In general, sub-basins that produce a high sediment yield in their greater slope and studies reported that when slope increased runoff decreased [72].

\section{Conclusions}

In this study, the SWAT model was applied and the results obtained suggest that the model is efficient in simulating streamflow and sediment concentration. As the model performance evaluation statistics shows, the model calibration and validation results of streamflow and sediment yield were in a good agreement with measured values. For instance, the coefficient of determination $\left(R^{2}\right)$ of 0.87 , Nash-Sutcliffe Efficiency (NSE) of 0.84 and PBIAS of -8.25 for stream flows was obtained for the calibration 


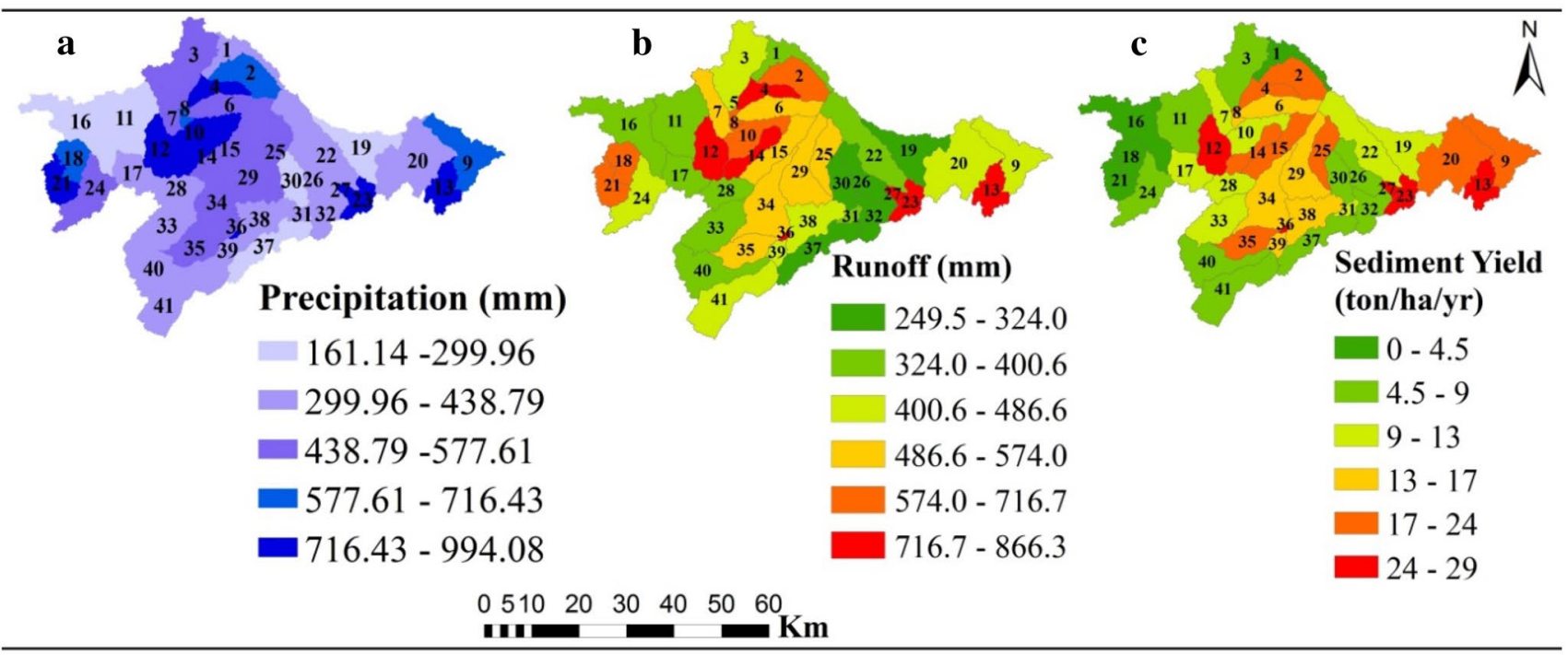

Fig. 10 Relationship between a precipitation, $\mathbf{b}$ runoff and $\mathbf{c}$ sediment yield of Kesem Dam Watershed

Fig. 11 Impact of precipitation and surface runoff on sediment yield

Fig. 12 Each sub basin slopesediment yield relationships
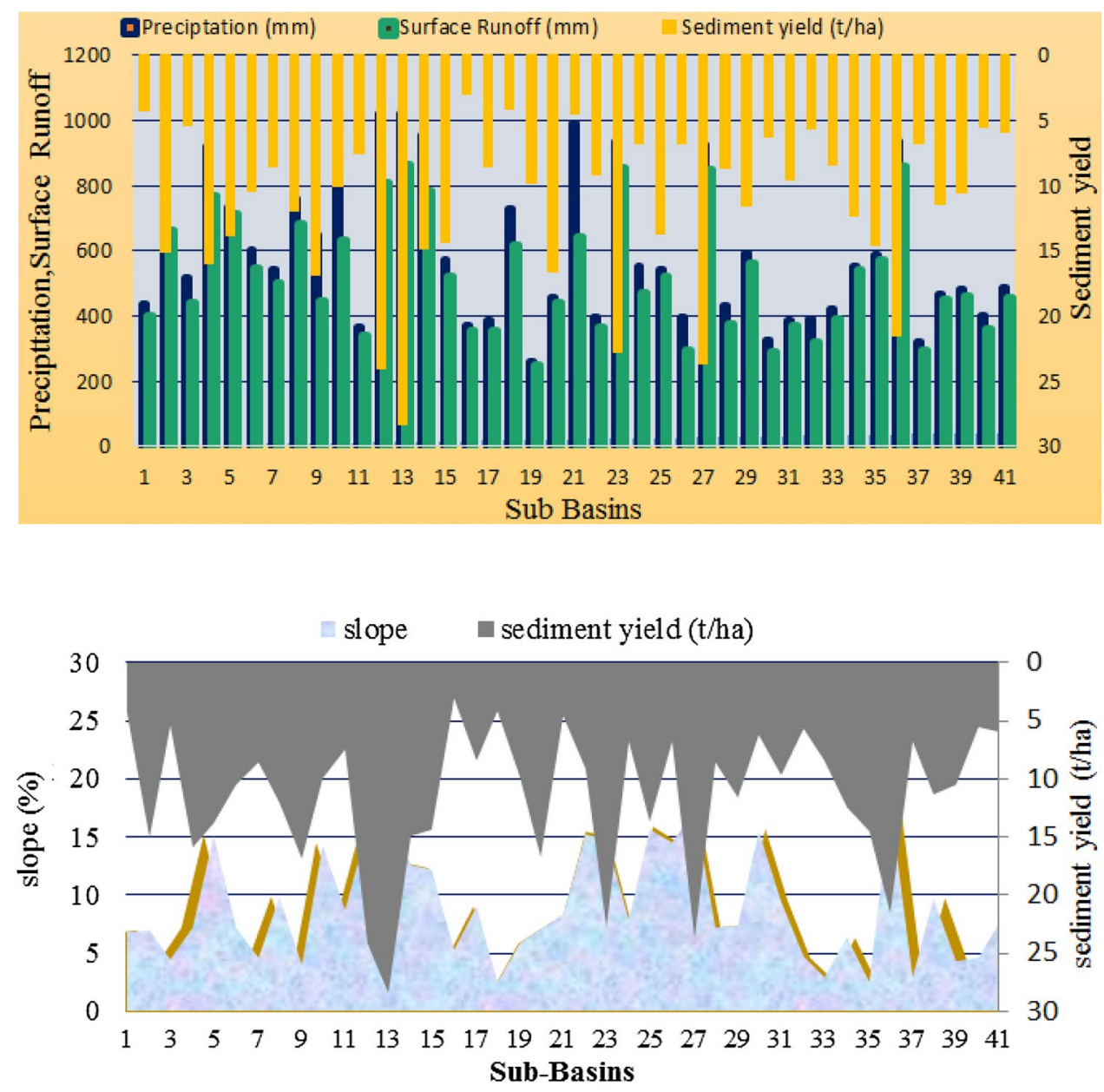
period (2001-2006). And; also $R^{2}$ of 0.85 , NSE of 0.84 and PBIAS of 7.29 for sediment yield for the calibration period (2001-2006). On the other hand, during the validation period (2001-2006) the results of $R^{2}$, NSE and PBIAS are respectively $0.86,0.87$ and 4.03 for stream flow and also $\mathrm{R}^{2}$, NSE and PBIAS are respectively $0.77,0.76$ and 14.4 for sediment sediment yields.

The spatial distributions of the runoff and sediment yield showed sub-basin 12 and 13 have high runoff rates and sediment yields among the 41 sub-basins generated by the SWAT model of the Kasem dam watershed that was observed during the heavy rainfall and land use/ land cover. Subbasin 12 (812.4 mm and $24.08 \mathrm{t} / \mathrm{ha})$ and $13(866 \mathrm{~mm}$ and $28.37 \mathrm{t} / \mathrm{ha}$ ) are in the highest runoff and sediment yield distributions. The water reservoir and other infrastructures in these sub-basin and the whole Kesem dam watershed alter due to the critical sediment yields and therefore, the study watershed needs conservation measures for the future sustainable uses and infrastructure development.

Acknowledgements We gratefully acknowledge of Ministry of Water, Irrigation and Electricity, National meteorological agency (NMA) and Ministry of Agriculture of Ethiopia for their all rounded support and cooperation in availing the necessary data. The authors also would like to express their sincere gratitude to anonymous reviewers and editors for their constructive comments and suggestions through scientific discussions, which really helped in the revision of the manuscript.

\section{Compliance with ethical standards}

Conflict of interest The authors declare that there are no conflict of interest associated in this manuscript.

Open Access This article is distributed under the terms of the Creative Commons Attribution 4.0 International License (http://creativeco mmons.org/licenses/by/4.0/), which permits unrestricted use, distribution, and reproduction in any medium, provided you give appropriate credit to the original author(s) and the source, provide a link to the Creative Commons license, and indicate if changes were made.

\section{Appendix: Averaged basin values of surface runoff and sediment yield}

\begin{tabular}{llllll}
\hline $\begin{array}{l}\text { Sub } \\
\text { basin }\end{array}$ & $\begin{array}{l}\text { Surface } \\
\text { runoff } \\
(\mathrm{mm})\end{array}$ & $\begin{array}{l}\text { Sedi- } \\
\text { ment } \\
\text { yield }(\mathrm{t} / \\
\text { ha) }\end{array}$ & $\begin{array}{l}\text { Sub } \\
\text { basin }\end{array}$ & $\begin{array}{l}\text { Surface } \\
\text { Runoff } \\
(\mathrm{mm})\end{array}$ & $\begin{array}{l}\text { Sediment } \\
\text { yield }(\mathrm{t} / \\
\text { ha) }\end{array}$ \\
\hline
\end{tabular}

\begin{tabular}{llrrrr}
\hline \multicolumn{6}{c}{ Mean annual surface runoff and sediment yield } \\
1 & 400.56 & 4.24 & 22 & 387.91 & 9.14 \\
2 & 666.51 & 15.03 & 23 & 858.43 & 22.72 \\
3 & 440.64 & 5.32 & 24 & 471.75 & 6.76 \\
4 & 772.81 & 15.92 & 25 & 523.40 & 13.69 \\
\hline
\end{tabular}

\begin{tabular}{|c|c|c|c|c|c|}
\hline $\begin{array}{l}\text { Sub } \\
\text { basin }\end{array}$ & $\begin{array}{l}\text { Surface } \\
\text { runoff } \\
(\mathrm{mm})\end{array}$ & $\begin{array}{l}\text { Sedi- } \\
\text { ment } \\
\text { yield (t/ } \\
\text { ha) }\end{array}$ & $\begin{array}{l}\text { Sub } \\
\text { basin }\end{array}$ & $\begin{array}{l}\text { Surface } \\
\text { Runoff } \\
(\mathrm{mm})\end{array}$ & $\begin{array}{l}\text { Sediment } \\
\text { yield (t/ } \\
\text { ha) }\end{array}$ \\
\hline 5 & 716.74 & 13.79 & 26 & 395.32 & 6.72 \\
\hline 6 & 547.35 & 10.47 & 27 & 850.29 & 23.70 \\
\hline 7 & 505.18 & 8.56 & 28 & 475.33 & 8.59 \\
\hline 8 & 785.04 & 11.98 & 29 & 565.17 & 11.53 \\
\hline 9 & 447.87 & 16.83 & 30 & 339.48 & 6.26 \\
\hline 10 & 634.11 & 9.97 & 31 & 373.65 & 9.59 \\
\hline 11 & 441.02 & 7.45 & 32 & 324.00 & 5.65 \\
\hline 12 & 812.37 & 24.08 & 33 & 394.78 & 8.34 \\
\hline 13 & 866.30 & 28.37 & 34 & 541.52 & 12.35 \\
\hline 14 & 785.99 & 14.83 & 35 & 573.98 & 14.52 \\
\hline 15 & 525.92 & 14.32 & 36 & 859.40 & 21.57 \\
\hline 16 & 457.76 & 2.99 & 37 & 298.43 & 6.70 \\
\hline 17 & 455.10 & 8.47 & 38 & 453.73 & 11.36 \\
\hline 18 & 619.74 & 4.09 & 39 & 462.16 & 10.50 \\
\hline 19 & 265.48 & 9.72 & 40 & 362.99 & 5.48 \\
\hline 20 & 443.07 & 16.62 & 41 & 459.15 & 5.88 \\
\hline 21 & 643.90 & 4.50 & & & \\
\hline \multirow{2}{*}{\multicolumn{2}{|c|}{ Average basin value }} & \multicolumn{2}{|c|}{ Surface runoff } & \multicolumn{2}{|l|}{543.67} \\
\hline & & \multicolumn{2}{|c|}{ Sediment yield } & 11.43 & \\
\hline
\end{tabular}

The averaged basin value of surface runoff and sediment yield from sub basin 1-41

\section{References}

1. Arnold J, Fohrer N (2005) SWAT2000: current capabilities and research opportunities in applied watershed modelling. Hydrol Process 19(3):563-572

2. Borah D, Bera M (2003) Watershed-scale hydrologic and nonpoint-source pollution models: review of mathematical bases. Trans ASAE 46(6):1553-1566

3. Arnold JG, Srinivason R, Muttiah RR, Williams JR (1998) Large area hydrologic modeling and assessment part I: model development. J Am Water Resour Assoc 34(1):73-89

4. Ben-Asher J, Humborg G (1992) A remote sensing model for linking rainfall simulation with hydrographs of a small arid watershed. Water Resour Res 28(8):2041-2047

5. Critchley W, Siegert K, Chapman C, Finkel M (1991) Water harvesting: a manual for the design and construction of water harvesting schemes for plant production. AGL/MISC/17/91, FAO, Roma

6. Raghunath HM (2006) Hydrology: principles, analysis and design. New Age International (P) Limited, Publishers, New Delhi

7. ICOLD, International Commission on Large Dams (1989) Sedimentation control of reservoirs/Maîtrise de l'alluvionnement des retenues. Committee on Sedimentation of Reservoirs. Paris, France

8. Putuhena W, Cordery I (1996) Estimation of interception capacity of the forest floor. J Hydrol 180:283-299. https://doi. org/10.1016/0022-1694(95)02883-8

9. Chandler DG, Walter MF (1998) Runoff responses among common land uses in the upland of Matalom, Leyte, Philippians. Trans ASAE 41:1635-1641 
10. Lee SW, Hwang SJ, Lee SB, Hwang HS, Sung HC (2009) Landscape ecological approach to the relationships of land use patterns in watersheds to water quality characteristics. Landsc Urban Plan 92:80-89

11. Fan J, Morris GL (1992) Reservoir sedimentation. I: deltas and density current deposits. J Hydraul Eng 118(3):354-369

12. Meyer LD, Wischmeier WH (1969) Mathematical simulation of the process of soil erosion by water. Trans Am Soc Agric Eng 12:754-758

13. de Lima JLMP, Tavares P, Singh VP, de Lima MIP (2009) Investigating the nonlinear response of soil loss to storm direction using a circular soil flume. Geoderma 152(1-2):9-15

14. Parsons AJ, Stone PM (2006) Effects of intra-storm variations in rainfall intensity on interrill runoff and erosion. Catena 67(1):68-78

15. Morgan RPC (1986) Soil erosion and conservation. Longman, New York

16. Wainwright J, Brazier RE (2011) Slope systems. In: Thomas DSG (ed) Arid zone geomorphology: process, form and change in drylands. Wiley, Hoboken. ISBN 978-0-470-71076-0

17. McCully P (1996) The ecology and politics of large dams. Silenced Rivers, London

18. Upadhya R, Pandey K, Upadhyay SK, Bajpai A (2012) Annual sedimentation yield and sediment characteristics of upper lake, Bhopal, India. J Chem Sci 2(2):65-74

19. Ella VB (2005) Simulating soil erosion and sediment yield in small upland watersheds using the WEPP model. In: Coxhead I, Shiverly GE (eds) Land use change in tropical watersheds: evidence, cause and remedies. CABI Publishing, Wallingford, Oxfordshire, pp 109-125

20. Bezuayehu T (2006) People and dams: environmental and socio-economic impacts of Fincha'a hydropower dam, western Ethiopia. Tropical Res. Manag. Paper, No. 75. Wageningen University and Research Center, Wageningen, The Netherlands

21. Tulu T (2002) Soil and water conservation for sustainable agriculture. CTA, Mega Publishing Enterprise, Addis Ababa

22. The Guardian (2007) Global food crisis looms as climate change and population growth strip fertile land. http://www. guardian.co.uk/environment/2007/aug/31/climatechange. food

23. Ingram J, Lee J, Valentin C (1996) The GCTE soil erosion network: a multidisciplinary research program. J Soil Water Conserv 51:377-380

24. IGBP (International Geosphere-Biosphere Programme) (1995) Land-use and land cover change. Science Research Plan, Stockholm, p 123

25. Takken I, Jetten V, Govers G, Nachtergaele J, Steegen A (2001) The effect of tillage-induced roughness on runoff and erosion patterns. Geomorphology 37:1-14

26. Evans R (1977) Overgrazing and soil erosion on hill pastures with particular reference to the Peak District. J Br Grassl Soc 32:65-76

27. Evans R (1997) Soil erosion in the UK initiated by grazing animals. A need for a national survey. Appl Geogr 17:127-141

28. Phillips J, Yalden D, Tallis J (1981) Peak District moorland erosion study. Phase 1 report. Peak Park Joint Planning Board, Bake-well

29. Linsley RK (1982) Hydrology for engineers. Ray K. Linsley, Jr., Max A. Kohler, Joseph L. H. Paulhus, 3rd edn. McGraw-Hill, New York

30. Daniel EB, Camp JV, Le Boeuf* EJ, Penrod JR, Dobbins JP, Abkowitz MD (2011) Watershed modeling and its applications: a stateof-the-art review. Vanderbilt University, VU Station B 351831, Nashville, Tennessee 37235-1831, USA

31. Borah DK, Bera M (2003) Watershed-scale hydrologic and nonpoint source pollution models: review of mathematical bases. $J$ ASAE 46(6):1553-1566
32. Young RA, Onstad CA, Bosch DD (1995) AGNPS: an agricultural nonpoint source model. In: Singh VP (ed) Computer models of watershed hydrology. Water Resources Publications, Highlands Ranch

33. Bosch D, Theurer F, Bingner R, Felton G, Chaubey I (2001) Evaluation of the AnnAGNPS water quality model. Southern Cooperative Series Bulletin, Tifton, GA

34. Downer CW, Ogden FL (2004) GSSHA: a model for simulating diverse streamflow generating processes. J Hydrol Eng 9(3):161-174

35. USDA (2008) The kinematic runoff and erosion model (KINEROS). http://www.tucson.ars.ag.gov/kineros/. Accessed 23 Nov 2009

36. Graham DN, Butts MB (2006) Flexible integrated watershed modeling with MIKE SHE. In: Singh VP (ed) Watershed models. CRC Press, Boca Raton

37. Jain SK, Tyagi J, Singh V (2010) Simulation of runoff and sediment yield for a Himalayan watershed using SWAT model. J Water Resour Prot 2:267-281

38. Lelis TA, Calijuri ML (2010) Hydrosedimentological modeling of watershed in southeast Brazil, using SWAT. Interdiscip J Appl Sci 2(5):158-174

39. Jeong J, Kannan N, Arnold J, Glick R, Gosselink L, Srinivasan R (2010) Development and integration of sub-hourly rainfallrunoff modeling capability within a watershed model. J Water Resour Manag 24(15):4505-4527

40. Saleh A, Du B (2004) Evaluation of SWAT and HSPF within BASINS program for the upper North Bosque River watershed in central Texas. Trans ASAE 47(4):1039-1049

41. Xu ZX, Pang JP, Liu CM, Li JY (2009) Assessment of runoff and sediment yield in the Miyun Reservoir catchment by using SWAT model. Hydrol Process 23:3619-3630

42. Arnold JG, Moriasi DN, Gassman PW, Abbaspour KC, White MJ, Srinivasan R, Santhi C, Harmel RD, Van Griensven A, Van Liew MW, Kannan N, Jha MK (2012) SWAT: model use, calibration, and validation. Trans ASABE 55:1491-1508

43. Jha MK, Gassman PW (2014) Changes in hydrology and streamflow as predicted by a modelling experiment forced with climate models. Hydrol Process 28(5):2772-2781

44. Fadil A, Rhinane H, Kaoukaya A, Kharchaf Y, Alami Bachir O (2011) Hydrologic modeling of the bouregreg watershed (Morocco) using GIS and SWAT model. J Geogr Inf Syst 3:279-289

45. Wolde K, Bogale G (2017) Effect of land use land cover dynamics on hydrological response of watershed: case study of Tekeze Dam watershed, northern Ethiopia. Int Soil Water Conserv Res 5(2017):1-16. https://doi.org/10.1016/j.iswcr.2017.03.002

46. Setegn SG, Srinivasan R, Dargahi B, Melessa AM (2009) Spatial delineation of soil Vulnerability in the Lake Tana Basin, Ethiopia. Hydrol Process 23:3738-3750

47. Tesfahunegn GB, Vlek PLG, Tamene L (2012) Management strategies for reducing soil degradation through modeling in a GIS environment in northern Ethiopia catchment. Nutr Cycl Agro Ecosyst 92:255-272

48. Tadele K, Forch G (2007) Impact of land use/land cover change on stream flow: a case study of hare watershed, Ethiopia. FWU Water Resource Publication, vol 06, pp 80-84. ISSN No. 1613-1045

49. Setegn SG, Dargahi B, Srinivasan R, Assefa M (2010) Modeling of sediment yield from Anjeni-Gauged watershed, Ethiopia using swat model. J Am Water Resour Assoc 46(3):514-526

50. Yesuf HM, Assen M, Alamirew T, Melesse AM (2015) Modeling of sediment yield in Maybar gauged watershed using SWAT, northeast Ethiopia. Catena 127:191-205

51. Betrie GD, Mohamed YA, van Griensven A, Srinivasan R (2011) Sediment management modeling in the Blue Nile Basin using SWAT model. Hydrol Earth Syst Sci 15(3):807-818. https://doi. org/10.5194/hess-15-807 
52. Mengistu DT, Sorteberg A (2012) Sensitivity of SWAT simulated streamflow to climatic changes within the Eastern Nile River basin. Hydrol Earth Syst Sci 16(2):391-407. https://doi. org/10.5194/hess-16-391-2012

53. Setegn SG, Dargahi B, Srinivasan R, Melesse AM (2010) Modeling of sediment yield from Anjeni-Gauged watershed, Ethiopia using SWAT model. J Am Water Resour Assoc 46(3):514-526. https://doi.org/10.1111/j.1752-1688.2010.00431.x

54. Wosenie MD, Verhoest N, Pauwels V, Negatu TA, Poesen J, Adgo E et al (2014) Analyzing runoff processes through conceptual hydrological modeling in the Upper Blue Nile Basin, Ethiopia. Hydrol Earth Syst Sci 18(12):5149-5167. https://doi.org/10.5194/ hessd-11-5287-2014

55. WWDSE and WPCOS (2005) Kesem-Kebena dam and irrigation project. Water works design and supervision enterprise in association with water and power consultancy service India. Draft final report. Addis Ababa, Ethiopia

56. Neitsch SL, Arnold JG, Kiniry JR, Srinivasan R, Williams JR (2005) Soil and water assessment tool, user manual, version 2000. Grassland, Soil and Water Research Laboratory, Temple

57. Neitsch SL, Arnold JG, Kiniry JR, Williams JR (2009) Soil and water assessment tool theoretical documentation, version 2009. USDA Agricultural Research Service and Texas A\&M Blackland Research Center, Temple, TX

58. Soil Conservation Service (SCS) (1972) National engineering handbook, section 4: hydrology. Department of Agriculture, Washington, DC, $762 \mathrm{p}$

59. Williams JR (1975) Sediment yield prediction with universal equation using runoff energy factor. In: Present and prospective technology for predicting sediment yield and sources: proceedings of the sediment yield workshop. USDA Sedimentation Lab., Oxford, Mississippi, November 28-30, 1972, ARS-S-40, pp 244-252

60. Neitsch SL, Arnold JG, Kiniry JR, Srinivasan R, Williams JR (2002) Soil and water assessment tool, user manual, version 2000. Grassland, Soil and Water Research Laboratory, Temple

61. Nash JE, Sutcliffe JV (1970) River flow forecasting through conceptual models: part 1. A discussion of principles. J Hydrol 10(3):282-290
62. Santhi C, Arnold JG, Williams JR, Dugas WA, Srinivasan R, Hauck LM (2001) Validation of the SWAT model on a large river basin with point and nonpoint sources. J Am Water Resour Assoc 37(5):1169-1188

63. Stigler SM (1989) Francis Galton's account of the invention of correlation. Stat Sci 4(2):73-79

64. Moriasi DN, Arnold JG, Van Liew MW, Bingner RL, Harmel RD, Veith TL (2007) Model evaluation guidelines for systematic quantification of accuracy in watershed simulations. Soil Water Div ASABE 50(3):885-900

65. Gupta HV, Sorooshian S, Yapo PO (1999) Status of automatic calibration for hydrologic models: comparison with multilevel expert calibration. J Hydrol Eng 4(2):135-143

66. Ma L, Ascough JC II, Ahuja LR, Shaffer MJ, Hanson JD, Rojas KW (2000) Root zone water quality model sensitivity analysis using Monte Carlo simulation. Trans ASAE 43(4):883-895

67. Van Liew MW, Arnold JG, Bosch DD (2005) Problems and potential of autocalibrating a hydrologic model. Trans ASAE 48(3):1025-1040

68. Karl TR, Knight RW (1998) Secular trends of precipitation amount, frequency, and intensity in the USA. Bull Am Meteor Soc 79:231-241

69. Nearinga MA, Jettenb V, Baffautc $C$, Cerdand $O$, Couturierd A, Hernandeza M, Le Bissonnaise $Y$, Nicholsa MH, Nunesf JP, Renschlerg CS, Souchèreh V, van Oosti K (2005) Modeling response of soil erosion and runoff to changes in precipitation and cover. Catena 61(2005):131-154

70. Francis CF, Thornes JB (1990) Runoff hydrographs from three Mediterranean vegetation cover types. In: Thornes JB (ed) Vegetation and erosion. Wiley, Chichester, pp 363-384

71. Wischmeier WH, Smith DD (1978) Predicting rainfall erosion losses. A guide to conservation planning. The USDA Agricultural Handbook No. 537, Maryland

72. Parsons AJ, Brazier RE, Wainwright J, Powell DM (2006) Scale relationships in hillslope runoff and erosion. Earth Surface Process Landforms 31:1384-1393. https://doi.org/10.1002/esp.1345

Publisher's Note Springer Nature remains neutral with regard to jurisdictional claims in published maps and institutional affiliations. 